\title{
3. Ist die Objektsprache ontologisch neutral?
}

So wie Terence Horgan vertritt auch Frank Jackson die Auffassung, dass Äußerungen ontologisch neutral sein können. Jackson nennt seine Version dieser Auffassung eine "modifizierte referentielle Theorie". ${ }^{1}$ Gemäß dieser Theorie gibt es zwar ontologische Festlegung, aber nicht auf der Ebene der Objektsprache, sondern ausschließlich auf der Ebene der Metasprache:

Consider the true sentence "Mr Pickwick is Dickens's most famous character". The (traditional) referentialist seeks to avoid having to admit Mr Pickwick into his ontology by searching for an allegedly innocuous paraphrase. But suppose, instead, we try to say straight out why accepting the sentence does not ontologically commit us to Mr Pickwick. Surely it is in full accord with the basic thought behind the Referential theory to put the matter thus. "Mr Pickwick is Dickens's most famous character" does not force us to acknowledge the existence of $\mathrm{Mr}$ Pickwick because "Mr Pickwick" in this sentence fails to denote, it is a name in form only. If we assented to "'Mr Pickwick' denotes Dickens's most famous character", then we would be admitting Mr Pickwick into our ontology, but it is, precisely, the latter sentence which we should not assent to. Mr Pickwick is Dickens's most famous character; but "Mr Pickwick" does not denote Dickens's most famous character, it does not denote anything. In short, the crucial question is not what one assents to in the object language, but what one assents to in the metalanguage which explicitly states the semantical roles of the terms in the object language. $^{2}$

Die Anerkennung von Sätzen der Objektsprache soll also grundsätzlich keinerlei ontologische Festlegungen mit sich bringen. Erst auf der Ebene der Metasprache müsse man ontologisch Farbe bekennen.

In the case of general terms, true ontological seriousness is indicated by preparedness to express one's sentences in terms of the semantic relation of being true of or application. Thus, when we assent to "There are comic characters in Dickens", our assent is not to be granted ontological status unless we are prepared also to assent to "There are things which 'is a comic character in Dickens' applies to". And those who hold (as most do) that fictional characters ought not to be admitted into one's ontology, can express this by saying that though there are comic characters in Dickens, "is a comic character in Dickens" does not apply to anything. ${ }^{3}$

\footnotetext{
${ }^{1}$ Jackson 1980.

${ }^{2}$ Ebd., 310.

${ }^{3}$ Ebd.
} 
Es geht also nicht darum, ob man einen Satz der Objektsprache als wahr anerkennt oder nicht, sondern es geht darum, welche Wahrheitsbedingungen für einen Satz angenommen werden. Und so soll gelten: Der Satz "Mr Pickwick ist Dickens' berühmteste Figur" ist wahr; aber für die Wahrheit dieses Satzes soll es nicht Bedingung sein, dass "Mr Pickwick" etwas bezeichnet, und es soll nicht Bedingung sein, dass das Prädikat "ist Dickens' berühmteste Figur” auf irgendetwas zutrifft. Man kann also, gemäß Jacksons modifizierter referentieller Semantik, den Satz

(1) Mr. Pickwick is Dickens's most famous character.

als wahr akzeptieren, ohne sich auf die Existenz von Mr. Pickwick festzulegen. Eine ontologische Festlegung auf Mr. Pickwick soll nur dann vorliegen, wenn man den metasprachlichen Satz

(1a) "Mr. Pickwick" denotes Dickens's most famous character.

als wahr akzeptiert. Außerdem soll das Akzeptieren des objektsprachlichen Satzes

(2) There are comic characters in Dickens.

keine ontologische Festlegung auf fiktive Figuren mit sich bringen. Wenn eine Person jedoch den metasprachlichen Satz

(2a) There are things which "is a comic character in Dickens" applies to. akzeptiert, dann ist diese Person auf die Existenz fiktiver Figuren festgelegt. Das impliziert, dass der Satz

(1) Mr. Pickwick is Dickens's most famous character.

wahr sein kann, während der metasprachliche Satz

(1a) "Mr. Pickwick" denotes Dickens's most famous character.

falsch ist. Andernfalls könnte eine Person ja nicht den Satz (1) als wahr akzeptieren und zugleich (1a) als falsch verwerfen, ohne inkonsistent zu sein; und nichts deutet darauf hin, dass Jackson für das Vermeiden ontologischer Festlegungen auf fiktive Gegenstände den Preis der Inkonsistenz bezahlen will. Vielmehr soll es offenbar konsistenterweise möglich sein, (1) zu akzeptieren und zugleich (1a) als falsch zu verwerfen. Aus denselben Gründen muss gemäß Jacksons Theorie gelten, dass der objektsprachliche Satz (2) wahr sein kann, auch wenn (2a) falsch ist. Gemäß der referentiellen Semantik sind aber die Sätze (1a) und (2a) nichts anderes als Formulierungen der Wahrheitsbedingungen für (1) und (2). Jacksons modifizierte referentielle 
Theorie läuft also, ebenso wie Horgans kontextuelle Semantik, auf ein Aufgeben der referentiellen Semantik hinaus: Zumindest in manchen Fällen sollen nicht die Wahrheitsbedingungen der referentiellen Semantik gelten.

Es erhebt sich, wie schon bei Horgans kontextueller Semantik, auch hier die Frage: Wenn für Sätze wie (1) und (2) nicht die Standard-Wahrheitsbedingungen der referentiellen Semantik gelten, welche Wahrheitsbedingungen gelten dann? Auch Jackson hält nichts von Paraphrasierungsstrategien. Im Gegensatz zu Horgan macht er aber nicht einmal den Versuch, alternative Wahrheitsbedingungen für Sätze mit unliebsamen ontologischen Konsequenzen zu finden. Seine Lösung besteht offenbar vielmehr darin, auf die Angabe von Wahrheitsbedingungen überhaupt zu verzichten:

The traditional Referential theory, particularly Quine's version of it, frequently plays a polemic role. It is appealed to as a way of forcing an admission of ontological commitment from someone. Consider, for example, a person who assents to "I have at least one false belief". On the orthodox Referential theory, he is convicted of ontological commitment to objects of belief; for the sentence is obviously equivalent to "There is something false such that I believe it".

On the other hand, on the modified theory, he cannot be so convicted. He can be so convicted only if he ventures into the semantical metalanguage and assents to something like "There is something which 'is a false belief of mine' applies to". He can always avoid ontologically committing himself by refusing to express matters in the semantical metalanguage. However, he can buy this immunity only at a prize. He will be unable to tell us about the semantic roles parts of sentences play in determining the truth or falsity of those sentences. He will lack any articulated theory of how the meanings of sentences are related to the semantic roles of their parts. Therefore, the modified theory does not allow one to escape ontological commitment as easily as one might at first suppose. ${ }^{4}$

Man hat also für das Vermeiden einer ontologischen Festlegung doch einen Preis zu bezahlen, und zwar den des völligen Verzichts auf Wahrheitsbedingungen. Damit wird jede Verbindung zwischen Denken und Sprechen einerseits und der gedanken- und sprachunabhängigen Wirklichkeit andererseits vollkommen abgeschnitten. Unsere Gedanken und Sätze, die sich dem Anschein nach auf eine gedanken- und sprachunabhängige Wirklichkeit beziehen, sind in keiner Weise mehr in dieser Wirklichkeit "verankert". Wenn für einen Satz p keine Wahrheitsbedingungen formuliert werden können, dann wird nicht nur unklar, was es heißt, dass $\mathrm{p}$ wahr ist. Es wird auch unklar,

${ }^{4}$ Ebd., 314. 
was es heißt, dass eine Person dem Satz p zustimmt, den Satz als wahr akzeptiert. Denn in welchem Sinn kann man einem Satz p zustimmen, wenn man grundsätzlich nicht in der Lage ist, irgendwelchen Wahrheitsbedingungen für p zuzustimmen? Es wird dann auch unklar, was es heißt, einen Satz zu verstehen. Denn in welchem Sinn kann man behaupten, einen Satz $\mathrm{p}$ zu verstehen, wenn man grundsätzlich nicht in der Lage ist anzugeben, wie die Welt beschaffen sein muss, damit p wahr ist? In welchem Sinn kann ein Satz überhaupt eine Bedeutung haben, wenn es grundsätzlich unmöglich ist anzugeben, was der Fall sein muss, damit der Satz wahr ist? Gemäß Jacksons modifizierter referentieller Theorie sind ontologische Festlegungen zu vermeiden um den Preis des Aufgebens aller Verbindungen zwischen Bedeutung, Wahrheit und Welt. Dieser Preis ist mir zu hoch. Daher verwerfe ich auch diese Version der Neutralitätsthese. 